\title{
Relative Performance of Parent and Hybrid Cultivars of Gladiolus (Gladiolus hybridus Hort.) for Post-Harvest Attributes and Response to Different Holding Solutions
}

\author{
Zahoor Ahmed $^{1 *}$, K.K. Dhatt ${ }^{2}$ and Kushal Singh ${ }^{2}$ \\ ${ }^{1}$ Krishi Vigyan Kendra Kupwara, Sher-e-Kashmir University of Agricultural Sciences and \\ Technology of Kashmir- 190 025, India \\ ${ }^{2}$ Department of Floriculture and Landscaping, Punjab Agricultural University, \\ Ludhiana-141 004, Punjab, India
}

*Corresponding author

\begin{tabular}{|c|c|}
\hline & A B S T R A C T \\
\hline & \multirow{6}{*}{$\begin{array}{l}\text { The experiment was conducted during two consecutive years (2012-13 and 2013-14) to } \\
\text { assess the mean performance of hybrid and parent cultivars and their response towards } \\
\text { holding solutions. Hybrid cultivars were found to perform better than their parents for the } \\
\text { characters under study. Among all the cultivars tested, Punjab Glance statistically at par } \\
\text { with Punjab Glad } 1 \text { and Punjab Lemon Delight took minimum days to opening of basal } \\
\text { floret ( } 1.89 \text { days). Punjab Glad } 1 \text { recorded maximum vase life }(6.40 \text { days), absorption } \\
\text { spike }(75.80 \mathrm{ml}) \text { and per cent opening of florets. Punjab Glad } 1 \text { statistically at par with } \\
\text { Punjab Flame recorded maximum number of florets open at one time }(4.58) \text {. Punjab Glad } \\
1 \text { statistically at par with Punjab Pink Elegance and Punjab Glance recorded maximum } \\
\text { floret diameter }(9.26 \mathrm{~cm}) \text {. The estimation of heterobeltiosis for post harvest parameters } \\
\text { was observed to be desirable in all the hybrid cultivars except Punjab Lemon delight and } \\
\text { highest heterobeltiosis ( } 39.45 \%) \text { was recorded by Punjab Glad } 1 \text { for vase life. The sugar } \\
\text { treatments were found to be significant in affecting the post harvest quality parameters in } \\
\text { both parent and hybrid cultivars as compared to control. Among holding solutions, sucrose } \\
(2 \%) \text { plus aluminium sulphate ( } 400 \text { ppm) exhibited early opening of basal floret ( } 2.12 \\
\text { days) and maximum vase life ( } 4.81 \text { days), number of florets open at one time }(4.10) \text {, floret } \\
\left.\text { diameter }(9.07 \mathrm{~cm}) \text {, water or solution absorption spike }{ }^{-1} \text { ( } 59.86 \mathrm{ml}\right) \text { and per cent opening of } \\
\text { florets. }\end{array}$} \\
\hline Keywords & \\
\hline $\begin{array}{l}\text { Gladiolus } \\
\text { (Gladiolus hybridus } \\
\text { Hort.) }\end{array}$ & \\
\hline Article Info & \\
\hline $\begin{array}{l}\text { Accepted: } \\
\text { 24 January } 2018 \\
\text { Available Online: } \\
\text { 10 February } 2018\end{array}$ & \\
\hline & \\
\hline
\end{tabular}

\section{Introduction}

Gladiolus is an important bulbous plant mainly used for cut flower purposes. It is grown for its fascinating spikes opening gradually from base to top. It is a popular flower and grown in almost all the climatic zones of India. The gladiolus spikes are highly perishable and is susceptible to large post harvest loses. However, the floret longevity is very short surviving for 4 to 6 days (Mayak et $a l ., 1973)$ and the senescence of florets is 
generally due to depletion of carbohydrates. Although, this is an ethylene insensitive bulbous plant but oxidative stress has been considered as one of the major causes of senescence (Ali et al., 2008). The senescence of these elegant flowers could be delayed through various approaches like development of improved cultivars and use of vase life extending solutions. Gladiolus being a vegetative propagated plant, hybridization coupled with selection through vegetative propagation is the best approach to combine desirable traits in an individual (Hancock, 2004). Another advantage is that the identification of one genotype with superior hybrid combination is sufficient, because vegetative propagation fixes heterozygosity and non-additive interactions and allows the multiplication of even sterile genotypes (McKey et al., 2010). Another approach of extending the vase life is the use of vase solutions, however the optimum concentration of these solutions differs with the species, variety or even in same variety grown under different climatic conditions. Moreover different flowers and varieties are reported to differ in their vase life due to genetic, physiological or anatomical characteristics (Nowak and Rudnicki, 1990; Singh et al., 2001; Redman et al., 2002; Bala et al., 2008a). A large number of the chemicals which can extend the vase life are not generally used by the farmers either due to their non availability or because of their complex nature. So there is a need to search for those chemicals that are readily available, affordable and easy to handle. Therefore the present investigation was undertaken to find out the performance of hybrid cultivars in relation to their parents and their response toward the vase solutions.

\section{Materials and Methods}

The present investigation was carried out in the laboratory of Department of Floriculture and Landscaping, PAU Ludhiana during two successive years (2012-13 and 3013-14). The cut spikes were procured from the Research Farm of Department of Floriculture and Landscaping, PAU Ludhiana, Punjab which comprised of five hybrid cultivars and seven parent cultivars. The spikes were harvested at $\mathrm{S}_{2}$ stage (5-6 florets show colour), kept in a bucket with tap water and then transferred to laboratory. The spikes were cut $25 \mathrm{~cm}$ below the basal floret and fresh weight of the spikes was recorded before holding them in different solutions. The cut spikes were kept in $500 \mathrm{ml}$ beakers each with $400 \mathrm{ml}$ of solution. The cut spikes were subjected to chemical treatments containing sucrose $2 \%$, dextrose $2 \%$ and fructose $2 \%$ along with $400 \mathrm{ppm}$ of aluminium sulphate in each sugar treatment. During the experiment the temperature of Laboratory fluctuated between $20 \pm 2^{\circ} \mathrm{C}$ with relative humidity approximately $68 \pm 2 \%$ and irradiance was supplemented from cool white fluorescence lamps. In order to determine the performance of hybrid cultivars over its parents, heterosis over better parent (heterobeltiosis) was estimated.

$\left(\mathrm{F}_{1}\right.$ hybrid performance $\left.-\mathrm{bp}\right)$

Heterobeltiosis $=$ $\mathrm{x} 100$

$\mathrm{bp}$

Where $b p=$ performance of better parent

The observations were recorded on days taken to opening of basal floret, vase life, number of florets open at one time, floret diameter, solution or water absorption spike ${ }^{-1}$ and per cent opening of florets. The vase life was measured from the day of opening of basal floret up to last five florets remained open on the spike. In case less than five florets opened, wilting of basal floret was considered as termination of vase life. Volume absorbed spike $^{-1}$ was measured up to wilting of last floret. Maximum number of florets open at one time was recorded by counting the open florets on each spike daily. The data collected 
were subjected to statistical analysis using complete randomized design (CRD). Significant effects of treatments were identified by analyzing data using SAS software version 9.1 (SAS Institute, Cary, North Carolina, USA).

\section{Results and Discussion}

The parents and hybrids of gladiolus differed significantly in days taken to opening of basal floret (Table 1). Happy End was observed to be early parent that took minimum days to basal floret opening (1.98 days) while as Sylvia appeared to be late in days to opening of basal floret (4.26 days). Among hybrid cultivars Punjab Glance statistically at par with Punjab Glad 1 and Punjab Lemon Delight took minimum days to opening of basal floret (1.89 days). Punjab Flame took maximum number of days to opening of basal floret (2.8 days) as compared to other hybrid cultivars. All the hybrid cultivars except Punjab Flame have shown negative heterobeltiosis for opening of basal floret over late as well as early parent, indicating that Punjab Flame has achieved earliness in opening of basal floret over its better parent. Both the early and late opening of florets may be desirable as it extends the flowering period in vase. This change in the character might have occurred due to recombination of genes during crossing. Differences in the rate of opening of florets in gladiolus cultivars have also been reported by Singh et al., (2009). Perusal of data (Table 2 and 3) indicated that True Yellow recorded highest vase life (4.59 days) and number of florets open at one time (3.85) among parent cultivars and Punjab Glad 1 recorded highest vase life (6.40 days) and number of florets open at one time (4.58) among hybrids. All the hybrid cultivars except Punjab Lemon Delight have shown positive heterobeltiosis for vase life and numbers of florets open at one time. Punjab Glad 1 has recorded highest heterobeltiosis (39.43\%) for vase life, thereby suggesting the significant improvement of this character in this hybrid. This improvement in the character might have occurred due to diverse nature of the parents involved in recombination. Similar results were also reported by Patra and Mohanty, (2015). Floret diameter was observed to be higher for hybrid cultivars as compared to parents (Table 4). Punjab Glad 1 statistically at par with Punjab Pink Elegance and Punjab Glance recorded maximum floret diameter $(9.26 \mathrm{~cm})$ and Suchitra exhibited minimum floret diameter $(6.16 \mathrm{~cm})$ among both parent and hybrid cultivars. All the hybrid cultivars have recorded positive heterobeltiosis for floret diameter. Punjab Glad 1 followed by Punjab Flame recorded maximum amount of absorption spike $^{-1}(75.80 \mathrm{ml})$ among hybrids and Yellow Stone followed by True Yellow registered higher absorption $\operatorname{spike}^{-1}(55.38 \mathrm{ml})$ among parents (Table 5). Punjab Glad 1 showed maximum heterobeltiosis for absorption spike ${ }^{-1}$ (37.59\%). Thus the hybrid cultivars have shown positive improvement in floret diameter and absorption spike ${ }^{-1}$ over its parents which might have occurred due to the diverse nature of its parents. Punjab Glad 1 followed by Punjab Flame showed maximum per cent opening of florets whereas minimum per cent opening of florets was shown by Sylvia (Fig. 1). Punjab Glance (Happy End x Yellow Stone) and Punjab Glad 1 (Happy End $\mathrm{x}$ True Yellow) exhibited positive heterosis over their respective parents. No significant improvement of Punjab Lemon Delight (Jacksonville Gold x White Prosperity) in per cent opening of florets had been achieved over its parents. Punjab Pink Elegance (Suchitra $x$ White Prosperity) and Punjab Flame (Sylvia $\mathrm{x}$ White prosperity) showed more resemblance to its female parent in per cent of florets, suggesting that the character might be inherited from White Prosperity. The opening of florets on the spike is genetically determined and considerable variations occur among varieties (Singh et al., 2009). 
Table.1 Mean performance of parent and hybrid cultivars in days taken to opening of basal floret under different treatment conditions

\begin{tabular}{|c|c|c|c|c|c|c|c|}
\hline \multicolumn{3}{|l|}{ Parents } & $\begin{array}{l}\text { S(2\%)+AS } \\
(400 \mathrm{ppm})\end{array}$ & $\begin{array}{l}\mathrm{F}(2 \%)+\mathrm{AS}( \\
400 \mathrm{ppm})\end{array}$ & $\begin{array}{l}\mathrm{D}(2 \%)+\mathrm{AS}( \\
400 \mathrm{ppm})\end{array}$ & Control & Mean \\
\hline \multicolumn{3}{|l|}{ Jacksonville Gold } & 1.30 & 2.30 & 2.33 & 3.01 & 2.23 \\
\hline \multicolumn{3}{|l|}{ Happy End } & 1.50 & 2.07 & 1.83 & 2.50 & 1.98 \\
\hline \multicolumn{3}{|l|}{ Suchitra } & 3.11 & 4.63 & 4.21 & 4.00 & 3.99 \\
\hline \multicolumn{3}{|l|}{$\overline{\text { Sylvia }}$} & 4.42 & 3.47 & 4.88 & 4.28 & 4.26 \\
\hline \multicolumn{3}{|l|}{ True Yellow } & 2.22 & 3.11 & 2.55 & 3.82 & 2.93 \\
\hline \multicolumn{3}{|l|}{ White Prosperity } & 1.50 & 3.03 & 2.50 & 3.33 & 2.59 \\
\hline \multicolumn{3}{|l|}{ Yellow Stone } & 3.02 & 2.89 & 3.33 & 2.43 & 2.92 \\
\hline \multirow[t]{2}{*}{ Hybrids } & \multicolumn{2}{|c|}{ Heterobetiosis (\%) } & & & & & \\
\hline & Late & Early & & & & & \\
\hline $\begin{array}{l}\text { Punjab Glad1 (Happy } \\
\text { End x True Yellow) } \\
\end{array}$ & -33.79 & -2.02 & 1.89 & 2.22 & 2.33 & 1.32 & 1.94 \\
\hline $\begin{array}{l}\text { Punjab Glance (Happy } \\
\text { End x Yellow Stone) } \\
\end{array}$ & -35.27 & -4.55 & 0.89 & 2.31 & 2.03 & 2.33 & 1.89 \\
\hline $\begin{array}{l}\text { Pink Elegance (Suchitra } \\
\mathrm{x} \text { White Prosperity) } \\
\end{array}$ & -38.60 & -5.40 & 2.07 & 2.50 & 2.55 & 2.67 & 2.45 \\
\hline $\begin{array}{l}\text { Punjab Lemon } \\
\text { Delight(Jacksonville } \\
\text { Gold x White Prosperity) }\end{array}$ & -24.70 & -12.56 & 1.13 & 2.14 & 1.95 & 2.57 & 1.95 \\
\hline $\begin{array}{l}\text { Punjab Flame (Sylvia } x \\
\text { White Prosperity) }\end{array}$ & -33.80 & 8.88 & 2.39 & 2.75 & 2.93 & 3.20 & 2.82 \\
\hline \multicolumn{3}{|l|}{ Mean } & 2.12 & 2.79 & 2.79 & 2.96 & \\
\hline
\end{tabular}

$\mathrm{S}=$ Sucrose $; \mathrm{F}=$ Fructose $; \mathrm{D}=$ Dextrose $; \mathrm{AS}=$ Aluminium sulphate

Table.2 Mean performance of parent and hybrid cultivars for vase life (day) under different treatment conditions

\begin{tabular}{|c|c|c|c|c|c|c|}
\hline \multicolumn{2}{|l|}{ Parents } & $\begin{array}{l}\text { S(2\%)+AS } \\
(400 \mathrm{ppm})\end{array}$ & $\begin{array}{l}\mathrm{F}(2 \%)+\mathbf{A S} \\
(400 \mathrm{ppm})\end{array}$ & $\begin{array}{l}\mathrm{D}(2 \%)+\mathrm{AS} \\
(400 \mathrm{ppm})\end{array}$ & Control & Mean \\
\hline \multicolumn{2}{|l|}{ Jacksonville Gold } & 3.70 & 3.43 & 4.00 & 2.67 & 3.45 \\
\hline \multicolumn{2}{|l|}{ Happy End } & 3.75 & 3.20 & 2.96 & 2.42 & 3.08 \\
\hline \multicolumn{2}{|l|}{ Suchitra } & 3.50 & 3.20 & 3.31 & 2.84 & 3.21 \\
\hline \multicolumn{2}{|l|}{ Sylvia } & 3.99 & 2.68 & 2.43 & 2.14 & 2.81 \\
\hline \multicolumn{2}{|l|}{ True Yellow } & 5.63 & 4.55 & 4.38 & 3.81 & 4.59 \\
\hline \multicolumn{2}{|l|}{ White Prosperity } & 5.44 & 4.44 & 4.22 & 3.89 & 4.50 \\
\hline \multicolumn{2}{|l|}{ Yellow Stone } & 4.66 & 3.55 & 3.44 & 3.33 & 3.75 \\
\hline Hybrids & Heterobetiosis (\%) & & & & & \\
\hline $\begin{array}{l}\text { Punjab Glad1 (Happy End } \\
\text { x True Yellow) } \\
\end{array}$ & 39.43 & 7.44 & 6.60 & 6.02 & 5.55 & 6.40 \\
\hline $\begin{array}{l}\text { Punjab Glance (Happy } \\
\text { End x Yellow Stone) } \\
\end{array}$ & 1.33 & 4.33 & 3.83 & 4.03 & 3.00 & 3.80 \\
\hline $\begin{array}{l}\text { Pink Elegance (Suchitra x } \\
\text { White Prosperity) }\end{array}$ & 3.33 & 5.66 & 5.22 & 4.22 & 3.51 & 4.65 \\
\hline $\begin{array}{l}\text { Punjab Lemon } \\
\text { Delight(Jacksonville Gold } \\
\text { x White Prosperity) }\end{array}$ & -28.00 & 3.77 & 3.33 & 3.00 & 2.86 & 3.24 \\
\hline $\begin{array}{l}\text { Punjab Flame (Sylvia x } \\
\text { White Prosperity) } \\
\end{array}$ & 18.67 & 5.82 & 5.42 & 5.50 & 4.61 & 5.34 \\
\hline \multicolumn{2}{|l|}{ Mean } & 4.81 & 4.12 & 3.96 & 3.39 & \\
\hline \multicolumn{2}{|l|}{ CD (5\%) } & \multicolumn{5}{|c|}{ Cultivar $=0.42 ;$ Concentration $=0.24 ;$ Interaction $=0.84$} \\
\hline
\end{tabular}

$\mathrm{S}=$ Sucrose $; \mathrm{F}=$ Fructose $; \mathrm{D}=$ Dextrose $; \mathrm{AS}=$ Aluminium sulphate 
Table.3 Mean performance of parent and hybrid cultivars for number of florets open at one time under different treatment conditions

\begin{tabular}{|c|c|c|c|c|c|c|}
\hline \multicolumn{2}{|l|}{ Parents } & $\begin{array}{l}\text { S(2\%)+ AS } \\
(400 \mathrm{ppm})\end{array}$ & $\begin{array}{l}\mathbf{F}(2 \%)+\mathrm{AS} \\
(400 \mathrm{ppm})\end{array}$ & $\begin{array}{l}\mathrm{D}(2 \%)+\mathrm{AS} \\
(400 \mathrm{ppm})\end{array}$ & Control & Mean \\
\hline \multicolumn{2}{|l|}{ Jacksonville Gold } & 3.74 & 3.64 & 3.50 & 3.31 & 3.55 \\
\hline \multicolumn{2}{|l|}{ Happy End } & 3.61 & 3.29 & 3.27 & 3.03 & 3.30 \\
\hline \multicolumn{2}{|l|}{ Suchitra } & 3.79 & 3.57 & 3.41 & 2.86 & 3.41 \\
\hline \multicolumn{2}{|l|}{$\overline{\text { Sylvia }}$} & 3.75 & 2.57 & 3.03 & 2.45 & 2.95 \\
\hline \multicolumn{2}{|l|}{ True Yellow } & 4.19 & 3.86 & 3.86 & 3.49 & 3.85 \\
\hline \multicolumn{2}{|l|}{ White Prosperity } & 4.09 & 3.76 & 3.70 & 3.41 & 3.74 \\
\hline \multicolumn{2}{|l|}{ Yellow Stone } & 3.91 & 3.79 & 3.67 & 3.25 & 3.66 \\
\hline Hybrids & Heterobeltiosis (\%) & & & & & \\
\hline $\begin{array}{l}\text { Punjab Glad1 (Happy End } \\
\mathrm{x} \text { True Yellow) } \\
\end{array}$ & 18.96 & 5.02 & 4.63 & 4.76 & 3.90 & 4.58 \\
\hline $\begin{array}{l}\text { Punjab Glance (Happy } \\
\text { End x Yellow Stone) } \\
\end{array}$ & 0.55 & 4.08 & 3.76 & 3.60 & 3.28 & 3.68 \\
\hline $\begin{array}{l}\text { Pink Elegance (Suchitra x } \\
\text { White Prosperity) }\end{array}$ & 6.95 & 4.40 & 4.03 & 3.86 & 3.71 & 4.00 \\
\hline $\begin{array}{l}\text { Punjab Lemon } \\
\text { Delight(Jacksonville Gold } \\
\text { x White Prosperity) }\end{array}$ & -6.15 & 3.92 & 3.52 & 3.31 & 3.28 & 3.51 \\
\hline $\begin{array}{l}\text { Punjab Flame (Sylvia } x \\
\text { White Prosperity) }\end{array}$ & 19.52 & 4.75 & 4.44 & 4.47 & 4.20 & 4.47 \\
\hline \multicolumn{2}{|l|}{ Mean } & 4.10 & 3.74 & 3.70 & 3.35 & \\
\hline CD (5\%) & & \multicolumn{5}{|c|}{ Cultivar $=0.20 ;$ Concentration $=0.11 ;$ Interaction $=0.39$} \\
\hline
\end{tabular}

$\mathrm{S}=$ Sucrose $; \mathrm{F}=$ Fructose $; \mathrm{D}=$ Dextrose $; \mathrm{AS}=$ Aluminium sulphate

Table.4 Mean performance of parent and hybrid cultivars for floret diameter $(\mathrm{cm})$ under different treatment conditions

\begin{tabular}{|c|c|c|c|c|c|c|}
\hline \multicolumn{2}{|l|}{ Parents } & $\begin{array}{l}S(2 \%)+A S \\
(400 \text { ppm) }\end{array}$ & $\begin{array}{c}\mathrm{F}(2 \%)+ \\
\mathrm{AS}(400 \mathrm{ppm})\end{array}$ & $\begin{array}{c}\mathrm{D}(2 \%)+\mathrm{AS} \\
(400 \mathrm{ppm})\end{array}$ & Control & Mean \\
\hline \multicolumn{2}{|l|}{ Jacksonville Gold } & 8.23 & 6.80 & 6.57 & 5.79 & 6.85 \\
\hline \multicolumn{2}{|l|}{ Happy End } & 9.17 & 8.32 & 8.00 & 7.53 & 8.26 \\
\hline \multicolumn{2}{|l|}{ Suchitra } & 6.50 & 6.07 & 6.12 & 5.96 & 6.16 \\
\hline \multicolumn{2}{|l|}{ Sylvia } & 7.50 & 6.27 & 6.10 & 5.65 & 6.38 \\
\hline \multicolumn{2}{|l|}{ True Yellow } & 8.53 & 7.88 & 7.98 & 6.83 & 7.81 \\
\hline \multicolumn{2}{|l|}{ White Prosperity } & 9.50 & 9.01 & 9.07 & 6.10 & 8.42 \\
\hline \multicolumn{2}{|l|}{ Yellow Stone } & \multirow[t]{2}{*}{8.59} & \multirow[t]{2}{*}{8.04} & \multirow[t]{2}{*}{8.20} & \multirow[t]{2}{*}{6.42} & \multirow[t]{2}{*}{7.81} \\
\hline Hybrids & Heterobetiosis (\%) & & & & & \\
\hline $\begin{array}{l}\text { Punjab Glad1 (Happy End } \\
\text { x True Yellow) }\end{array}$ & 12.11 & 10.63 & 9.63 & 9.49 & 7.30 & 9.26 \\
\hline $\begin{array}{l}\text { Punjab Glance (Happy } \\
\text { End x Yellow Stone) }\end{array}$ & 9.93 & 9.95 & 8.97 & 8.87 & 8.51 & 9.08 \\
\hline $\begin{array}{l}\text { Pink Elegance (Suchitra x } \\
\text { White Prosperity) }\end{array}$ & 8.79 & 10.37 & 8.73 & 9.10 & 8.44 & 9.16 \\
\hline $\begin{array}{l}\text { Punjab Lemon } \\
\text { Delight(Jacksonville Gold } \\
\text { x White Prosperity) }\end{array}$ & 0.36 & 9.50 & 8.18 & 9.30 & 6.83 & 8.45 \\
\hline $\begin{array}{l}\text { Punjab Flame (Sylvia } x \\
\text { White Prosperity) }\end{array}$ & 3.80 & 10.37 & 9.00 & 8.92 & 6.65 & 8.74 \\
\hline \multicolumn{2}{|l|}{ Mean } & 9.07 & 8.08 & 8.14 & 6.83 & \\
\hline \multicolumn{2}{|l|}{ CD $(5 \%)$} & \multicolumn{5}{|c|}{ Cultivar $=0.27 ;$ Concentration $=0.16 ;$ Interaction $=0.54$} \\
\hline
\end{tabular}

$\mathrm{S}=$ Sucrose $; \mathrm{F}=$ Fructose $; \mathrm{D}=$ Dextrose $; \mathrm{AS}=$ Aluminium sulphate 
Table.5 Mean performance of parent and hybrid cultivars for water or solution absorption spike ${ }^{-1}$ (ml) under different treatment conditions

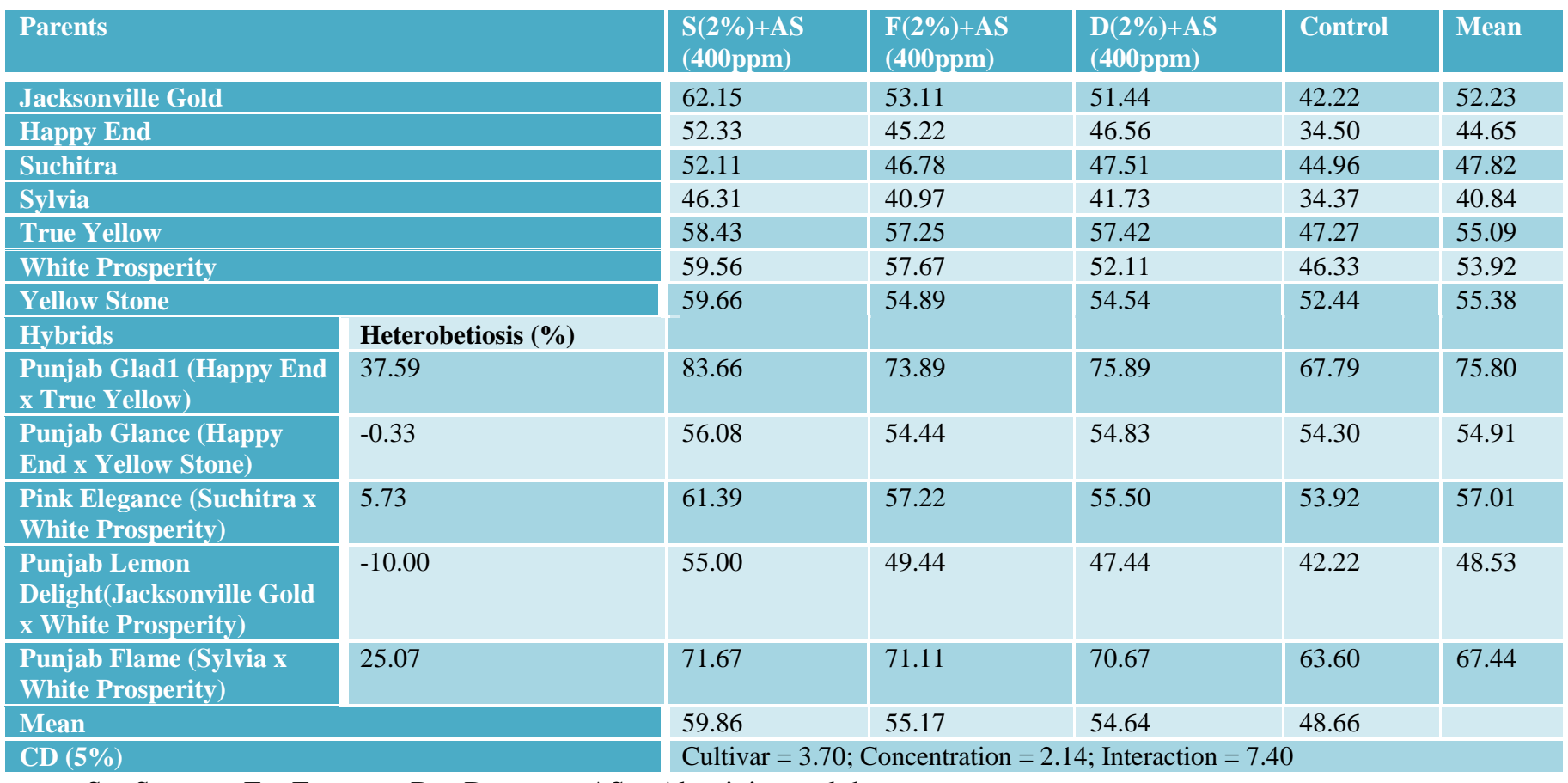

$\mathrm{S}=$ Sucrose $; \mathrm{F}=$ Fructose $; \mathrm{D}=$ Dextrose $; \mathrm{AS}=$ Aluminium sulphate

Fig.1 Effect of sugar plus aluminium sulphate treatments on percent opening of florets in gladiolus

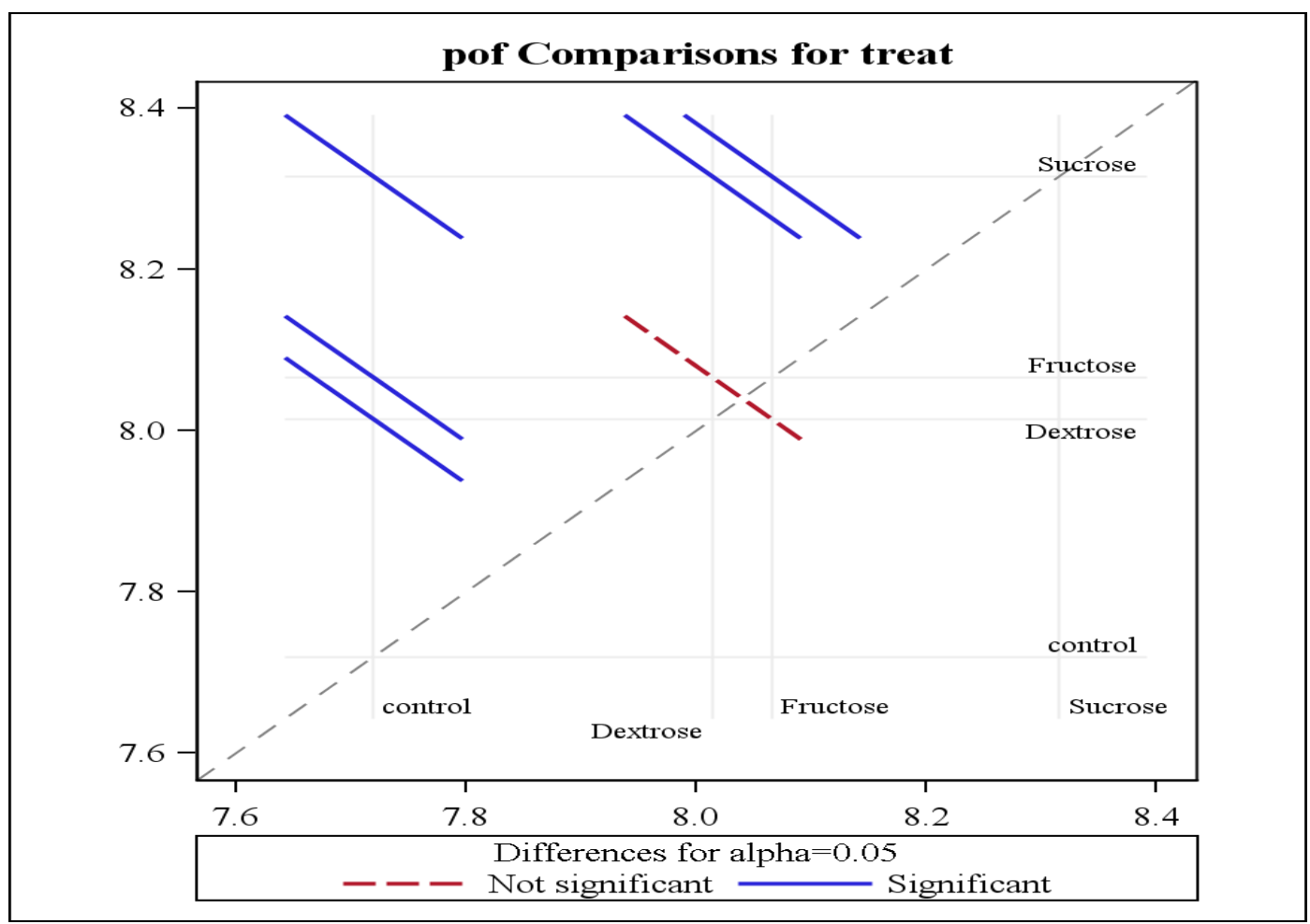


Fig.2 Interaction effect of sugar plus aluminium sulphate and cultivars percent opening of florets in gladiolus

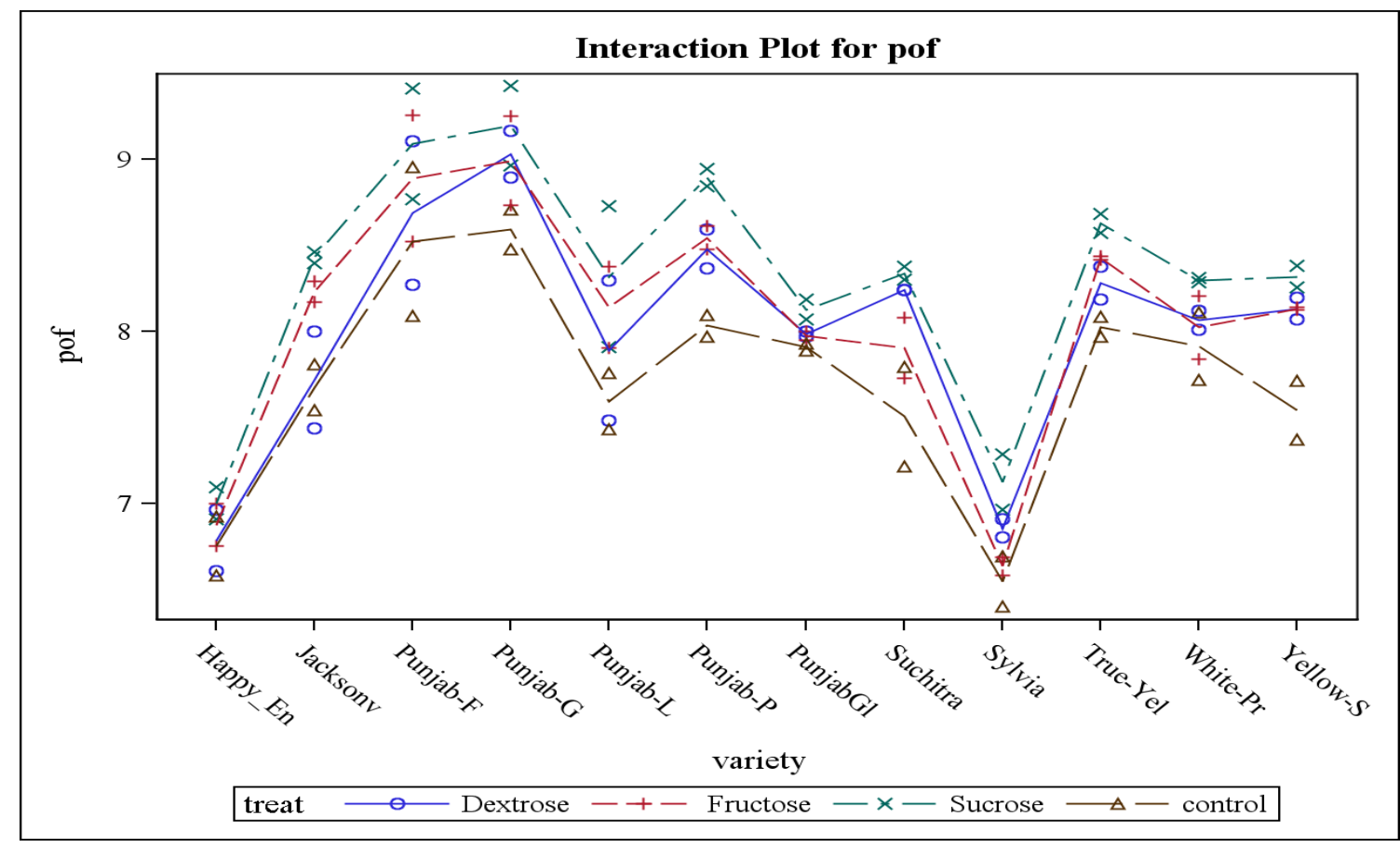

All the sugar plus aluminium sulphate treatments were found to be significant in improving the opening the basal florets, vase life, number of florets open at one time, floret diameter, solution absorption and per cent opening of florets as compared to control (Table 2-5). Vase solution containing Sucrose (2\%) plus aluminium sulphate (400 ppm) significantly hastened the opening of basal florets (2.12 days) and recorded longest vase life (4.81 days), number of florets open at one time (4.10), floret diameter $(9.07 \mathrm{~cm})$ and solution absorption spike $^{-1}(59.86 \mathrm{ml})$ as compared to control. Applied sucrose supplements the endogenous level thereby supplying additional respiratory substrate to facilitate early opening of basal floret. Sucrose induced the early opening of florets in gladiolus (Singh et al., 2000). The exogenous application of sucrose replaces the depletion of carbohydrates from cut stems and maintains the respiratory pool where as aluminium sulphate maintains a low $\mathrm{pH}$ which reduces the microbial blockage of vessels thereby prolonging the vase life. Thus inhibition of vascular occlusion and constant supply of soluble carbohydrates might be responsible for extended vase life of gladiolus spikes. Treatment with sucrose plus aluminium sulphate extended vase life of cut stems in gladiolus (Kumar et al., 2010).

Punjab Glance kept in sucrose plus aluminium sulphate solution took lowest number of days to opening of basal floret (0.89 days) while as Sylvia kept in dextrose solution took highest number of days to opening of basal florets (4.88 days) (Table 1). Gladiolus spikes are usually harvested at bud stage, and therefore, require large amount of carbohydrates for flower opening (Bala et al., 2008b). Punjab Glad 1 recorded maximum vase life (7.44 days), number of florets open at one time $(5.02)$, floret diameter $(10.63 \mathrm{~cm})$ and absorption spike $^{-1}(83.66 \mathrm{ml})$ when kept in sucrose plus aluminium sulphate solution where as lowest values were shown by spikes when kept in distilled water (Table 2-5). The 
accelerated opening of florets on sugar treated spikes require considerable amount of water and solution for cellular expansion and metabolic processes in the tepals which creates an osmotic potential and this osmotic potential is compensated by the absorption of water or sugar solution from the vase (Yamada et al., 2007). Gladiolus spikes kept in citric acid (200 ppm), $\mathrm{AgNO}_{3}(3.5 \%)$ and sucrose $(0.02 \%)$ enhanced the solution uptake (Tiwari et al., 2010). The holding solution containing sucrose $(1.5 \%)$ and $\mathrm{Al}_{2}$ $\left(\mathrm{SO}_{4}\right)_{3} 16 \mathrm{H}_{2} \mathrm{O}(300 \mathrm{ppm})$ increased the floret diameter and bud size in rose (Bala et al., 2008b). All the chemical treatments significantly improved the per cent opening of florets as compared to control (Figure 2). Sucrose plus aluminium sulphate treatment exhibited the highest per cent opening of florets. Fructose and dextrose plus aluminium sulphate were also significant in improving the percent opening of florets as compared to control but did not show any significant interaction with each other. Gladiolus is a multi-floret system that requires considerable amount of respiratory substrate and application of exogenous sucrose increases the vase life as well as opening of florets (Singh et al., 2000, Singh and Kumar, 2008). The holding solution containing sucrose (4\%) and $\mathrm{Al}_{2}\left(\mathrm{SO}_{4}\right)_{3} 16 \mathrm{H}_{2} \mathrm{O}(300 \mathrm{ppm})$ promoted per cent opening of florets (Nelofar and Paul, 2008)

All the hybrid cultivars except Punjab Lemon Delight showed positive improvement for all the characters under study. Punjab Glad 1 appears to be best hybrid cultivar for most of the characters and sucrose (2\%) plus aluminum sulphate (400 ppm) was found to be the best treatment for extending vase life.

\section{References}

Ali, S., F. U. Khan, F. A. Khan and S. A. Wani. 2008. Post harvest behaviour of cut daffodil as influenced by certain pulsing treatments. Journal of Ornamental Horticulture. 11 (2): 81-90.

Bala, M., R. Kumar and K. Singh. 2008a. Evaluation of rose (Rosa spp.) cultivars for post harvest attributes. Journal of Ornamental Horticulture. 11:77-78

Bala, M., R. Kumar and K. Singh. 2008b. Effect of pulsing and holding solutions on keeping quality of cut flowers of rose (Rosa spp.). Journal of Ornamental Horticulture. 11(1): 54-57.

Hancock, J. F. 2004. Plant evolution and the origin of crop species. CABI, Cambridge, 313p.

Kumar S., A. Kumar and S. Chandra. 2010. Effect of floral preservatives on vase life of gladiolus (Gladiolus grandiflorus L.). The Asian Journal of Horticulture 5(1): 44-48.

Mayak, S., B. Bradvo, A. Gvilli and A. H. Halevy. 1973. Improvement of opening of cut gladioli flowers by pre-treatment with high sugar concentrations. Scientia Horticulturae. 1: 357-365.

McKey, D., M. Elias, B. Pujol and A. Duputié. 2010. The evolutionary ecology of clonally propagated domesticated plants. New Phytologist. 186: 318-332.

Nelofar and T. M. Paul. 2008. Post harvest management of gladiolus. Journal of Ornamental Horticulture. 11(1): 69-71

Nowak, J and R. M. Rudnicki. 1990. Post Harvest Handling and Storage of Cut Flowers, Florist Greens and Potted Plants. Chapman and Hall, London, pp. 209.

Patra, S. K and C. R. Mohanty. 2015. Vase life study in different varieties of gladiolus. International Journal of Agricultural Science. 5(2): 27-32.

Redman, B. P., J. M. Dole, M. O. Maness and J. A. Anderson. 2002. Post harvest handling of nine speciality cut flower species. Scientia Horticulturae. 92: 293- 
303.

Singh, K and R. Kumar. 2008. Effect of carbon source on vase life and opening of florets in gladiolus spikes harvested at different stages of development. Journal of Ornamental Horticulture. 11: 287-89

Singh, K. P. J. Singh, J. S. Arora and R. P. S. Mann. 2000. Studies on post harvest management of gladiolus. Journal of Ornamental Horticulture. (New series) 3: $107-10$

Singh, K., J. S. Arora and S. K. Bhattacharjee. 2001. Postharvest Management of Cut Flowers. Tech. Bull. No. 10 Pp 39. All India Coordinated Research Project on Floriculture, IARI, New Delhi.
Evaluation of gladiolus varieties for post harvest keeping quality parameters. In: Atri N S, Gupta R C, Sagoo M I S and Singhal V L (ed.) Germplasm diversity and evaluation-angiosperms. Pp 85-91. Bishen Singh Mahendra Pal Singh, Dehra Dun, India.

Tiwari, A. K., B. D. Bhuj and S. K. Mishra, 2010. Impact of certain chemicals on vase life of different cultivars of China aster and gladioli. Indian Journal of Horticulture. 67(2): 255-259.

Yamada $\mathrm{T}$ Ito $\mathrm{M}$ Oyama $\mathrm{T}$ Nakada $\mathrm{M}$ Maesaka M and Yamaki S. 2007b. Analysis of sucrose metabolism during petal growth of cut roses. Postharvest Biology and Technology. 43: 174-77

Singh, K., R. Kumar and R. Singh. 2009.

\section{How to cite this article:}

Zahoor Ahmed, K.K. Dhatt and Kushal Singh. 2018. Relative Performance of Parent and Hybrid Cultivars of Gladiolus (Gladiolus hybridus Hort.) for Post-Harvest Attributes and Response to Different Holding Solutions. Int.J.Curr.Microbiol.App.Sci. 7(02): 2826-2834. doi: https://doi.org/10.20546/ijcmas.2018.702.344 